PLPB : Pendidikan Lingkungan dan Pembangunan Berkelanjutan

DOI : http://doi.org/10.21009/PLPB.201.03

DOI : 10.21009/PLPB

\title{
THE RELATIONSHIP BETWEEN SUBJECTIVE NORMS WITH HOUSEWIFE'S INTENTION TO ACT ON OF WASTE ISSUES IN CIDEPIT RIVER, SUB-DISTRICT OF SEMPLAK, CITY OF BOGOR
}

\author{
Septi Mulyanti Siregar ${ }^{1}$, Nadiroh $^{2}$, and Samadi $^{3}$ \\ Pendidikan Lingkungan, Pascasarjana Universitas Negeri Jakarta, \\ Komplek UniversitasNegeri Jakarta Gedung M. Hatta Jl. Rawamangun Muka, \\ Jakarta Timur, Indonesia 13220, email: ${ }^{\text {mulyantisiregar@gmail.com, }}{ }^{2}$ \\ nadiroh@unj.ac.id, dan ${ }^{3}$ samadi@unj.ac.id
}

\begin{abstract}
Disposing of litter into the river has become a habit for people living around the banks of rivers, rivers, rivers, rivers, and so on. The purpose of this study is to determine the relationship between prevailing norms and spending on littering housewives around the banks of the Cidepit river. This research was conducted in the area of RW 07, Semplak Village, Bogor City in May-June 2018 with a survey method using quantitative. The numbers of samples in this study were 116 people, variables consisting of, and intentions of garbage, and types of data. The second variable is primary data obtained through questionnaires by respondents. Based on the results obtained Pearson $r$ value of 0.319 with Sig. (2-tailed) equal to 0,000 or less than 0.05 Is there a positive relationship between subjective norms (subjective norms) and intentions of intentions in housewives around the banks of Cidepit River, RW 07, Semplak Village, Bogor city.
\end{abstract}

Keywords: intention, subjective norms, waste, river, housewife

Volume XX

\section{Nomor 1}

Maret 2019
e-ISSN : 2580-9199 


\section{PENDAHULUAN}

Kondisi lingkungan dibeberapa wilayah Indonesia statusnya sangat mengkhawatirkan sebagai contoh air sungai yang tercemar yang dilihat dari perubahan fisik airnya yang berubah warna menjadi keruH dan berbau, kemudian sampah yang menumpuk dibantaran sungai, udara yang semakin panas akibat minimnya pepohonan dan banyak hal lagi yang mengakibatkan kondisi lingkungan menjadi sangat mengkhawatirkan untuk kehidupan manusia. Sungai Cidepit di Kelurahan Semplak, Kecamatan Bogor Barat, Kota Bogor pada dasarnya berfungsi sebagai drainase karena berdasarkan letak geografis daerah ini memiliki curah hujan yang cukup tinggi yaitu antara 3500-4000 mm/tahun. Namun masyarakat disekitar bantaran sungai menggunakannya untuk kegiatan sehari-hari seperti mencuci, mandi dan sebagainya.

Peneliti juga menemukan bahwa terdapat pengendapan lumpur ditepian sungai sehingga lebar sungai menyempit, banyaknya sampah ditepian sungai dan adanya bekas pembakaran sampah, dan dibeberapa rumah membuang air hasil cucian rumah tangga dari kamar mandi rumah langsung ke sungai. Selain pendakalan sungai, ada yang disebut dengan eutrofikasasi yaitu pencemaran air yang disebabkan oleh munculnya nutrient yang berlebihan ke dalam ekosistem air sehingga merangsang pertumbuhan gangga yang nantinya akan merusak ekosistem sungai, nutrient berupa nitrogen dan fosfor yang salah satu sumbernya dari limbah rumah domestik.

Warga di daerah tersebut mengetahui bahwa sungai tidak sejernih dulu tetapi masyarakat hanya bisa berpasrah dikarenakan banyak keterbatasan yang dimiliki dan merasa tidak punya daya dan upaya untuk kembali membersihkan sungai tersebut. Penanganan sampah biasanya dibuang langsung ke sungai, dibakar dan hanya dibeberapa RT ada petugas kebersihan yang mengambil kemudian dibakar juga dan pada akhirnya tetap dibuang ke sungai. Data menunjukkan bahwa perilaku pemilahan sampah dan daur ulang penduduk Indonesia pada umumnya rendah, di mana hanya 
$10,09 \%$ rumah tangga Indonesia melakukan pemilahan sampah tanpa daur ulang, 8,75\% melakukan pemisahan sampah dengan daur ulang, sedangkan sisanya tidak memisahkan limbahnya (Badan Pusat Statistik, 2014)

Hasil peneliti mewawancarai ibu PKK (Pembinaan Kesejahteraan Keluarga), didapatkan bahwa sosialisasi terkait pengolahan sampah sudah dilakukan untuk menjadikan sampah non organik menjadi bungkus sabun, kopi, dan lainnya yang dijadikan dompet, tas, vas bunga, dan lainnya namun hal tersebut pun tidak berjalan berkelanjutan. Merujuk pada Theory Planned Behavior yang dikemukakan oleh Fishbein dan Ajzen bahwa teori perilaku terencana didasarkan pada asumsi bahwa seseorang dapat berperilaku bijaksana, maka orang tersebut harus memperhitungkan semua informasi yang ada secara implisit maupun eksplisit dan mempertimbangkan akibat dari perilaku yang diperbuat oleh dirinya sendiri, dan dijelaskan bahwa intensi terdiri dari 3 aspek yaitu: attitude toward the behavior, subjective norm, dan perceived control yang terdapat pada gambar 1 .

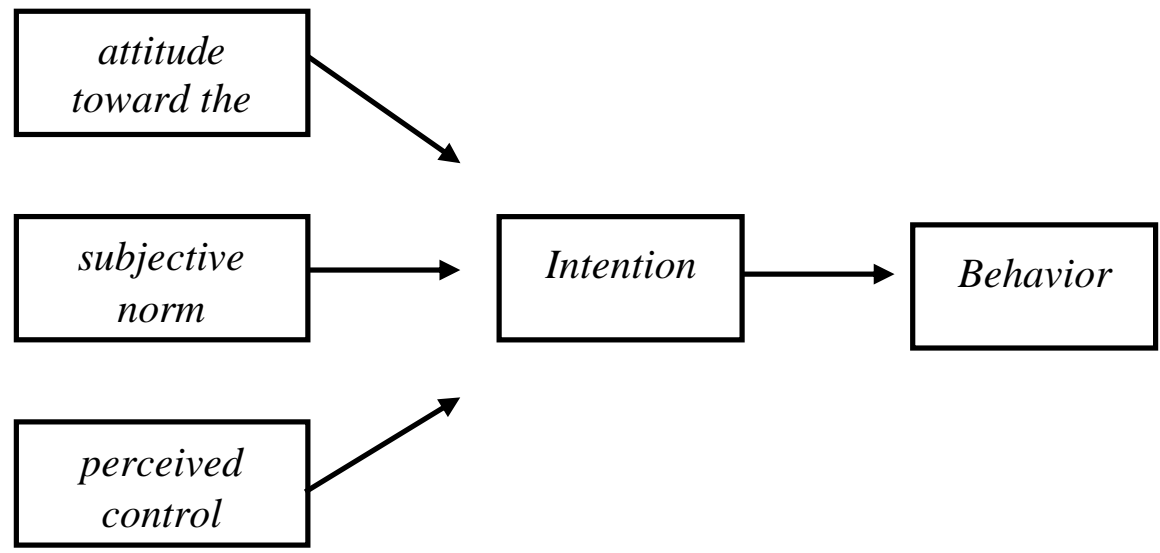

Gambar 1

Theory Planned Behavior, Ajzen 1991

Prediktor terbaik dari perilaku kognisi seseorang untuk melakukan adalah intensi yang mewakilkan perilaku tertentu, yang dianggap 
sebagai anteseden langsung dari perilaku. Maka, intensi bertindak dapat dipahami sebagai kesediaan untuk menyatakan bertindak atas perilaku tersebut. Seseorang memutuskan untuk berperilaku dapat dipengaruhi oleh sikap selain itu juga norma subyektif dan kontrol perilakunya (Ajzen, 1991).

Peran sikap, norma subyektif, dan kontrol perilaku sangat menentukan keiinginan seseorang dalam berperilaku yang akhirnya menentukan perilaku yang sebenarnya (Kanuk, dan L Schiffman, 2007). Kemauan masyarakat untuk merubah perilaku lebih peduli terhadap lingkungan masih minim, namun masih ada harapan, seharusnya hal ini menjadi pertimbangan para stakeholder untuk menggagas suatu trobosan untuk perubahan daerahnya. Norma subyektif merupakan persepsi individu tentang tekanan sosial untuk melakukan atau tidak melakukan perilaku suatu perilaku (Ajzen, 2005). ukuran tradisional. Terkadang norma subjektif ditemukan dapat menjadi memprediksi secara signifikan niat untuk mendaur ulang (Cheung, Chan, \& Wong, 1999; Steinheider et al., 1999), terkadang tidak (Boldero, 1995; Terry et al., 1999). Teori pada subjective norm (Cialdini et al., 1991) membedakannya menjadi dua yaitu norma sosial: norma injunctive atau aturan perilaku yang dibagi secara sosial dan deskriptif atau perilaku yang terlihat orang lain. Norma injunctive terkait kelompok sanksi, sedangkan norma deskriptif terkait dengan lokasi (Reno et al.,1993) yang disesuiakn dengan norma sosial yang berlaku pada satu waktu, individu akan mengikuti pedoman umum untuk berperilaku atau mematuhi norma hukum atau meniru tindakan orang lain dalam pengaturan yang sesuai dengan norma deskriptif.

Jadi dalam penelitian ini intensi perilaku membuang sampah ke sungai pada masyarakat adalah salah satu gejala yang nantinya akan berpotensi menjadikan perilaku yang sesungguhnya yang akan membawa dampak buruk bagi lingkungan. Artinya suatu kebiasaan yang telah 
terjadi biasa diubah untuk keberlangsungan lingkungan, adat adalah wujud ideal dari kebudayaan yang berfungsi sebagai pengatur kelakukan manusia, oleh karena sistem perilaku masyarakat membuang limbah atau sampah tersebut sudah berlangsung lama (turun-temurun), maka tindakan atau konsepsi itu telah menjadi sistem nilai budaya (culture value system) yang mempengaruhi pola berpikir mereka dan menjadi pedomanan berperilaku. Dijelaskan bahwa komponen norma subjektif dimaksudkan untuk menggambarkan pengaruh orang lain yang dianggap penting (important othersI) (Engel and Blackwell, 2006).

Kurangnya pengetahuan menjadikan masyarakat belum memiliki paradgma yang baik. Bagi mengetahui dijelaskan dalam peraturan negara bahwa sisa kegiatan rumah tangga seharusnya menjadi tanggung jawab disetiap rumah. Berdasarkan UU No. 18 Tahun 2008 tentang pengelolaan sampah, menjelaskan bahwa sampah adalah sisa kegiatan seharihari manusia atau proses alam yang berbentuk padat atau semi padat berupa zat organik atau anorganik bersifat dapat terurai atau tidak dapat terurai yang dianggap sudah tidak berguna lagi dan dibuang ke lingkungan. Kamus istilah lingkungan, sampah adalah bahan yang tidak mempunyai nilai atau tidak. Sampah adalah bagian dari suatu yang tidak dipakai, tidak disenangi atau sesuatu yang harus dibuang yang umumnya berasal dari kegiatan yang dilakukan oleh manusia atau industri tetapi bukan yang sifatnya biologis dan umumnya bersifat padat. Menurut Dainur (1992) menyatakan bahwa sampah adalah setiap bahan atau material yang untuk sementara tidak dapat dipergunakan lagi dan harus dibuang atau dimusnahkan. Berdasarkan jenisnya sampah terdiri dari sampah organik dan anorganik. Menurut Mundiyatun dan Daryanto (2015) sampah anorganik adalah sampah yang sulit diurai sehingga bertahan dalam wujudnya dan zatnya, sedangkan sampah organik adalah sampah yang 
mudah diurai oleh organisme. Sumber sampah diklasifikasikan menjadi beberapa kategori yaitu pemukiman penduduk, tempat-tempat umum dan perdagangan, sarana pelayanan milik pemerintah, industri, dan pertanian.

Menurut Fishbein dan Ajzen (1975) menyatakan bahwa ketika keinginan meningkat, maka kemungkinan perilaku pun akan meningkat, itu berarti jika keinginan memuang sampah tinggi maka perilaku membuang sampah juga akan meningkat. Jadi dapat disimpulkan bahwa intention dapat memprediksi perilaku (behavior). Kemudian disebutkan juga bahwa ada empat aspek dalam memprediksi intensi atau keinginan diantaranya: 1) Perilaku (behavior) yaitu perilaku yang akan dilakukan secara nyata, 2) Sasaran (target) yaitu dimana perilaku tersebut akan diarahkan. Objek yang menjadi sasaran dari perilaku tersebut dapat digolongkan menjadi tiga, yaitu orang/objek tertentu, sekelompok orang atau sekelompok objek pada umumnya, 3) Situasi (situation) yaitu suasana atau tempat yang mendukung untuk dilakukannya suatu perilaku, 4) Waktu (time), yaitu waktu dimana suatu perilaku akan dilakukan. Menurut Jogiyanto (2007) menyatakan norma subjektif adalah persepsi atau pandangan seseorang terhadap kepercayaan-kepercayaan orang lain yang akan mempengaruhi minat atau intensi untuk melakukan atau tidak melakukan perilaku yang sedang dipertimbangkan

Maka dalam penelitian ini Intensi Bertindak (Intention to act) Terhadap Persampahan adalah kecenderungan bertindak seseorang yang terlihat dari keyakinan yang mendalam sehingga pikiran diarahkan untuk mengambil keputusan, melakukan atau tidak melakukan dimasa sekarang atau dimasa yang akan datang terhadap isu persampahan. Kemudian norma subjektif adalah suatu persepsi atau pandangan individu terhadap kepercayaan-kepercayaan yang berlaku di lingkungannya sehingga mempengaruhi intensi untuk melakukan atau tidak melakukan 
perilaku yang diharapkan oleh orangorang terdekat yang berada dilingkungan sosialnya.

Berdasarkan permasalahan tersebut, maka peneliti sangat tertarik untuk mengetahui sejauh mana Hubungan Antara Norma Subjektif

\section{METODOLOGI PENELITIAN}

Penelitian ini menggunakan metode survey dengan variabel terikat dalam penelitian ini adalah intensi bertindak (intention to act) tehadap persampahan dan variabel bebas dalam penelitian ini adalah norma subjektif (subjective norm). Lokasi penelitian berada di RW 07, Kelurahan Semplak, Kota Bogor. Waktu pelaksanaan penelitian yaitu Bulan Juni 2018. Populasi dalam penelitian ini adalah masyarakat yang tinggal disekitar bantaran sungai Cidepit, Kota Bogor.

Pengambilan sampel dilakukan dengan cara random sampling. Sampel
Dengan Intensi Bertindak Ibu Rumah Tangga Terhadap Persampahan Di Bantaran Sungai Cidepit, RW 07, Kelurahan Semplak, Kota Bogor yang merujuk pada Theory of Reason Action. dalam penelitian ini adalah 116 orang yang merupakan seorang ibu rumah tangga.

Data dalam penelitian ini menggunakan kuesioner. Kuesioner dimaksud berupa daftar pertanyaan yang akan diberikan kepada subyek penelitian. Daftar pertanyaan yang disusun hasil dari konstruk teori dan sesuai dengan kisi-kisi. Instrumen intensi bertindak (intention to act) tehadap persampahan 1 pada tabel 1 dan kisi-kisi norma subjektif (subjective norm) pada Tabel 2.

Tabel 1

Instrumen Intensi Bertindak (Intention to Act) Tehadap Sampah

\begin{tabular}{l|c|c|c|}
\hline No & \multicolumn{2}{c}{ Indikator } & No. Butir \\
\hline \multicolumn{3}{|c|}{ Jumlah } \\
\hline Volume XX & Nomor 1 & Maret 2019 & e-ISSN : 2580-9199 \\
\hline
\end{tabular}




\begin{tabular}{|c|c|c|c|}
\hline \multicolumn{4}{|c|}{ Pertanyaan } \\
\hline 1 & Keinginan memilah sampah dari sumbernya & $1,2,3,5$ & 4 \\
\hline 2 & Keinginan menaati aturan tentang persampahan & $6,7,15,17$ & 4 \\
\hline 3 & $\begin{array}{l}\text { Keinginan memilih tempat pembuangan } \\
\text { sampah }\end{array}$ & $\begin{array}{c}4,8,9,10,11, \\
12,13,14,16, \\
18\end{array}$ & 10 \\
\hline & Total & & 18 \\
\hline
\end{tabular}

Tabel 2

Instrumen Norma Subjektif (Subjective Norm)

\begin{tabular}{cccc}
\hline No & Indikator & No. Butir Pertanyaan & Jumlah \\
\hline 1 & Normative Beliefs & $1,2,3,4,7,10,17$ & 7 \\
\hline 2 & Motivation to comply & $5,6,8,9,11,12,13,14,15,16$ & 10 \\
\hline \multicolumn{4}{c}{ Total } \\
\hline
\end{tabular}

\section{HASIL DAN PEMBAHASAN}

Berdasarkan hasil rata-rata hitung skor masing-masing indikator dari variabel intensi membuang sampah, terlihat bahwa indikator yang memiliki skor tertinggi adalah indikator Keinginan memilih tempat pembuangan sampah sebesar $34,59 \%$ dan indikator yang memiliki skor terendah adalah indikator Keinginan memilah sampah dari sumbernya sebesar 31,32\%. Untuk lebih jelasnya dapat dilihat pada tabel 3. Kemudian didapatka hasil rata-rata hitung skor masing-masing indikator dari variabel norma subjektif, terlihat bahwa indikator yang memiliki skor tertinggi adalah indikator Motivation to Comply sebesar 60,40\% dan indikator yang memiliki skor terendah adalah indikator Normative Beliefs sebesar $39,60 \%$.

Hasil perhitungan untuk menyusun model persamaan regresi antara norma subjektif (subjective norm) dengan intensi bertindak (intention to act) tehadap isu persampahan diperoleh konstanta regresi $\mathrm{a}=36,970$ dan koefisien korelasi $b=0,356$. (Tabel 3). sehingga pola hubungan antara kedua variabel ini dinyatakan oleh persamaan regresi $\hat{\mathrm{Y}}=36,970+0,356 \mathrm{X}$. Bentuk hubungan positif antara norma

\section{Volume XX}

Nomor 1
Maret 2019
e-ISSN : 2580-9199 
subjektif (subjective norm) dengan intensi bertindak (intention to act) tehadap isu persampahan ditunjukkan dengan nilai koefisien $r_{x y}=0,319$ (Gambar 1). Sebelum dilakukan analisis model persamaan dan menarik kesimpulan, maka dilakukan uji signifikansi dan linearitas persamaan regresi. Hasil perhitungan uji signifikansi dan linearitas disusun pada tabel ANAVA pada Tabel 4

Tabel 3

Koefisien Persamaan Regresi

\begin{tabular}{|c|c|c|c|c|c|c|}
\hline \multicolumn{7}{|c|}{ Coefficients $^{\mathrm{a}}$} \\
\hline & & \multicolumn{2}{|c|}{$\begin{array}{c}\text { Unstandardized } \\
\text { Coefficients }\end{array}$} & \multirow{2}{*}{$\begin{array}{c}\text { Standardized } \\
\text { Coefficients } \\
\text { Beta }\end{array}$} & \multirow[b]{2}{*}{$\mathrm{t}$} & \multirow[b]{2}{*}{ Sig. } \\
\hline \multicolumn{2}{|c|}{ Model } & $\mathrm{B}$ & Std. Error & & & \\
\hline \multirow[t]{2}{*}{1} & (Constant) & 36.970 & 5.218 & & 7.085 & .000 \\
\hline & $\begin{array}{l}\text { Norma } \\
\text { Subjektif }\end{array}$ & .356 & .099 & .319 & 3.592 & .000 \\
\hline
\end{tabular}

a. Dependent Variable: Intensi Bertindak (Intention to Act) Tehadap

Persampahan

Tabel 4

ANAVA untuk Uji Signifikansi dan Linearitas Persamaan Regresi

ANOVAa

\begin{tabular}{llrrrrr}
\hline \multirow{2}{*}{ Model } & \multicolumn{1}{c}{ Sum of } & & \multicolumn{2}{c}{ Mean } \\
Squares & df & Square & \multicolumn{1}{c}{ F } & \multicolumn{1}{c}{ Sig. } \\
\hline 1 & Regression & 473.156 & 1 & 473.156 & 12.902 & $.000^{\mathrm{b}}$ \\
\cline { 2 - 7 } & Residual & 4180.603 & 114 & 36.672 & & \\
\cline { 2 - 7 } & Total & 4653.759 & 115 & & &
\end{tabular}

a. Dependent Variable: Intensi Bertindak

b. Predictors: (Constant), Norma Subjektif

Persamaan regresi $\hat{Y}=\hat{Y}=\quad$ Persamaan tersebut menyatakan bahwa $36,970+0,356 \mathrm{X}$, untuk uji intensi bertindak dapat diperediksi dari signifikansi diperoleh tingkat prediktor subjective norm. signifikansi pada tabel sebesar $0,000<\quad$ Selanjutnya, hipotesis yang diajukan 0,05 maka persamaan regresi dalam penelitian ini adalah terdapat dinyatakan sangat positif signifikan. hubungan positif antara subjective 
norm (X) dengan intensi bertindak (intention to act) tehadap isu persampahan (Y).

Berdasarkan hasil perhitungan antara subjective norm dengan intensi bertindak (intention to act) tehadap isu persampahan bahwa diperoleh nilai Pearson's r sebesar 0,319 dengan Sig. (2-tailed) sebesar 0,000 atau lebih kecil dari $\alpha=0,05$ sehingga dapat dikatakan bahwa terdapat hubungan positif antara subjective norm dengan intensi bertindak (Tabel 4). Dengan kata lain makin tinggi norma subjektif maka makin baik $\mathrm{p}$ intensi bertindak. Adapun besarnya koefisien korelasi antara variabel $\mathrm{X}$ dengan $\mathrm{Y}$ dapat dilihat pada Tabel 5.

\section{Tabel 5}

Hubungan antara Environmental Sensitivity dengan Pelestarian Kearifan Lokal

\begin{tabular}{|c|c|c|c|}
\hline \multicolumn{4}{|c|}{ Correlations } \\
\hline & & Norma Subjektif & Intensi Bertindak \\
\hline & $\mathrm{N}$ & 116 & 116 \\
\hline \multirow[t]{4}{*}{ Norma Subjektif } & Pearson & 1 & $.319^{* * *}$ \\
\hline & Correlation & & \\
\hline & Sig. (2-tailed) & & .000 \\
\hline & $\mathrm{N}$ & 116 & 116 \\
\hline \multirow[t]{4}{*}{ Intensi Bertindak } & Pearson & $.319^{* * *}$ & 1 \\
\hline & Correlation & & \\
\hline & Sig. (2-tailed) & .000 & \\
\hline & $\mathrm{N}$ & 116 & 116 \\
\hline
\end{tabular}

**. Correlation is significant at the 0.01 level (2-tailed).

Norma subjektif masyarakat sosial yang melarangnya. Namun bantaran Sungai Cidepit yang negatif walaupun sungai tercemar masih ada menjadikan sungai terkena dampak beberapa masyarakat yang buruk, salah satunya kebiasaan memanfaatkannya untuk mandi, membuang sampah ke sungai dinilai mencuci dan lain sebagainya. Indikator biasa dan tidak ada aturan atau sanksi pertama dalam variabel norma 
subjektif dalam penelitian ini yaitu normative belief bahwa dihasilkan masyarakat di daerah bantaran sungai dalam penelitian ini tidak memiliki kepercayaan yang mengatur keindahan sungai yang harus dijaga atau kepercayaan sejak dulu yang diperuntukan khusus untuk menjaga perairan dilingkungannya. Kemudian indikator kedua yaitu motivation to comply menghasilkan bahwa norma yang berlaku dilingkungan ini didominasi oleh pengaruh motivasi orang disekitarnya seperti ibu-ibu pkk, ketua RT/RW/Lurah/Camat dan sebagainya sehingga jika ada dorongan dari tokoh tersebut maka aktivitas dapat dikontrol sehingga berhubungan langsung dengan intensi bertindak seseorang. Penelitian ini menguatkan bahwa norma-norma injunctive memiliki potensi besar untuk mengubah perilaku (Reno et al.,1993) yang dalam hal ini intensi bertindak yang merupakan predictor perilaku.

Berdasarkan pertanyaan yang diajukan oleh peneliti pada pertanyaan keinginan memilih tempat pembuangan sampah, maka intensi bertindak responden terhadap sampah menyatakan bahwa akan membuang ke tempat sampah jika tempat sampah dibuat secara menarik dan berwarnawarni sehingga ada keinginan tinggi untuk membuang sampah pada tempatnya. Sehingga secara psikologi sosial hal tersebut dapat menjadi intervensi sosial terkait dengan intensi bertindak terhadap sampah yang diterapkan disekitar masyarakat. Temuan ini juga mendukung penelitian sebelumnya bahwa ibu-ibu memiliki intensi kuat untuk membuang sampah ke sungai (Ghassani dan Yusuf, 2015) dan bahwa norma subjektif berada pada kategori tinggi dalam mempengaruhi intensi (Shanti, 2016). Kemudian dijelaskan juga norma subjektif adalah prediktor yang kuat untuk niat atau intensi berperilaku terkait secara positif dan signifikan dengan niat perilaku untuk menggunakan sistem perbankan di Yaman (Alqasa, et.al., 2014).

Adapun penelitian ini memiliki keterbatasan diantaranya hanya 
mengukur intensi bertindak terhadap sampah bukan perilakunya, namun norma subjektif dan intensi merupakan

\section{KESIMPULAN}

Berdasarkan hasil analisis data dan perhitungan statistik dapat disimpulkan bahwa terdapat Hubungan Positif Antara Norma Subjektif (Subjective Norm) dengan Intensi Bertindak (Intention to act) Tehadap Isu Persampahan Pada Ibu Rumah Tangga di Sekitar Bantaran Sungai Cidepit, Rw 07, Kelurahan Semplak,

\section{DAFTAR PUSTAKA}

Ajzen., dan Martin Fishbein. 1975. Belief, Attitude, Intention, and Behavior: An Introduction to Theory and Research. England: Addison Wesley. Ajzen. 1991. The Theory of Planned Behavior, Organizational Behavior and Human Process

Ajzen. 2005. Attitude, Personality, and Behavior Second Edition. USA: Open University Press.

Badan Pusat Statistik. 2014. Indikator perilaku peduli lingkungan hidup 2014. Jakarta: Badan Pusat Statistik. Retrieved from prediktor yang baik dalam aktivitas persampahan di masa depan.

Kota Bogor. Norma subjektif yang berlaku dimasyarakat bisa dibentuk dari motivasi yang diberikan para tokoh masyarakat untuk mendidik, maanfaatkan alam khususnya sungai dengan bijaksana dan menjaga lingkungan dari sampah sedari sumbernya yaitu rumah tangga.

Badan Pusat Statistik website: http://www.bps.go.id

Boldero, J. 1995. The prediction of household recycling of newspapers: The role of attitudes, intentions, and situational factors. Journal of Applied Social Psychology, 25(5), 440-462.

Cheung, S. F., Chan, D. K. S., \& Wong, Z. S. Y. (1999). Reexamining the theory of planned behaviour in understanding waste-paper recycling. Environment and Behaviour, 31(5), 587-612. 
Cialdini, R. B., Kallgren, C. A., \& Reno, R. R. 1991. A focus theory of normative conduct: A theoretical refinement and reevaluation of the role of norms in human behaviour. In M. P. Zanna (Ed.), Advances in experimental social psychology (Vol. 24, pp. 201-234). London: Academic Press.

Dainur. 1992. Materi-materi Pokok Ilmu Kesehatan Lingkungan. Jakarta: Widya Medika.

J. M. Hartono. 2007. Sistem Informasi Keperilakuan. Yogyakarta: Erlangga.

Jogiyanto. 2007. Sistem Informasi Keperilakuan. Yogyakarta: Penerbit Andi.

L. Kanuk, dan L Schiffman. 2007. Perilaku Konsumen. Jakarta: PT Indeks.

Alqasa, Khaled Mohammad., Isa, Filzah Mohd., Othman, Siti Norezam., and Zolait, Ali Husein. 2014. The Impact of student attitude and subjective norm on the behavioural intention to use services of banking system. Int. J. Business Information System, 15 (1), 105-122

Muhdiyatun dan Daryanto. 2015. Sanitasi Lingkungan dalam Agng Suprihatin (ed). Pengelolaan Kesehatan
Lingkungan. Yogyakarta: Gava Media.

Raisha Ghassani, dan Umur Yusuf. 2015. Intensi Membuang Sampah di Sungai Cikapundung pada Ibu-ibu RW 15 Kelurahan Tamasari, Bandung. Prosiding Penelitian Sivitas Akademika Unisba, Vol. 1, No. 2

Reno, R. R., Cialdini, R. B., \& Kallgren, C. A. 1993. The trans-situational influence of social norms._Journal of Personality and Social Psychology, 64(1), 104-112.

R. Triastity dan S. D. Saputri. 2013. Pengaruh Sikap dan Norma Subjektif Terhadap Niat Beli Mahasiswa Sebagai Konsumen Potensial Produk Pasta Gigi Pepsodent. Jurnal Gema, Vol. 25, No. 46

Shanti, Resti Elfia. 2016. Pengaruh Sikap Personal, Norma Subjektif dan Persepsi Kontrol Perilaku terhadap Intensi Kewirausahaan Siswa SMK DI UPTD Wilayah 1 Kabupaten Bandung, Jawa Barat. Universitas Pendidikan Indonesia: Tesis, Magister Program Studi Pendidikan Ekonomi

Slameto. 2003. Belajar Dan Faktorfaktor Yang 
Mempengaruhinya. Jakarta: Rineka Cipta.

Steinheider, B., Fay, D., Hilburger, T., Hust, I., Prinz, L., Vogelgesang, F., et al. 1999. Soziale Normen als Pra"diktoren von umweltbezogenem Verhalten. Zeitschrift fur Sozialpsychologie, 30(1), 4056.

Triandis Triandis, H.C. 1980. Value, Attitude, and Interpersonal Behavior. Lincoln NE: University of Nebraska Press.

Terry, D. J., Hogg, M. A., \& White, K. M. 1999. The theory of planned behaviour: Self-identity, social identity and group norms. British Journal of Social Psychology, 38(3), 225-244. doi:10.1348/014466699164149

Wirawan Sarlito. 2002. Psikologi Sosial dan Individu dan Teoriteori Sosial. Jakarta: Balai Pustaka. 